\title{
Profile of canine patient with esophageal foreign bodies
}

\author{
Perfil del paciente canino con cuerpos extraños esofágicos
}

\author{
Carlos Rodríguez-Alarcón, ${ }^{1}$ Ph.D, Diana Beristain R, ${ }^{1 *}$ Ph.D, Ramón Rivera $B,{ }^{1} \mathrm{Ph} . \mathrm{D}$, \\ Eva Pérez $M,{ }^{2} \mathrm{Ph} . \mathrm{D}$, Jesús Usón $\mathrm{C}_{1}^{2} \mathrm{Ph} . \mathrm{D}$.
}

\begin{abstract}
${ }^{1}$ Universidad Autónoma de Ciudad Juárez, Departamento de Ciencias Veterinarias, Hospital Veterinario Universitario, Ciudad Juárez, México. 'Universidad de Extremadura, Facultad de Veterinaria, Hospital Clínico Veterinario, Cáceres, España. *Correspondencia: diana.beristain@uacj.mx, marcela. beristain@gmail.com
\end{abstract}

Received: September 2013; Accepted: August 2014.

\begin{abstract}
Objective. Determine the profile of the canine patient with esophageal foreign bodies to identify risk factors associated with the foreign bodies. Materials and Methods. This is a retrospective study made by the Veterinary Hospital Clinic of the Universidad de Extremadura (VHC). Different factors were analyzed in dogs with an endoscopic diagnosis of esophageal foreign bodies. Results. This pathology was more commonly found in young adult dogs and in small breeds. This pathology was present for the first time in the Portuguese Warren Hound, which was also the breed with the highest risk. Conclusions. The results obtained in this investigation are in agreement with the previous description of a patient that presents esophageal foreign bodies. Also, the Portuguese Warren Hound was found to be predisposed to this problem, with a higher risk factor than other breeds previously mentioned in the literature. To prevent esophageal foreign bodies, dogs should be fed raw meat and bones, especially small breeds. This pathology should always be kept in mind in dogs with esophagitis symptomology regardless of age, although it is most common in young adult dogs.
\end{abstract}

Key Words: esophagitis, esophagoscopy, risk factor (Source: MeSH).

\section{RESUMEN}

Objetivo. Determinar el perfil del paciente canino que presenta cuerpos extraños esofágicos para identificar las características de riesgo al presentar esta entidad. Materiales y métodos. Este es un estudio retrospectivo realizado en el Hospital Clínico Veterinario de la Universidad de Extremadura $(\mathrm{HCV})$. Se analizaron diferentes parámetros de los perros que presentaron un diagnóstico endoscópico de cuerpos extraños esofágicos. Resultados. Esta patología se presentó más comúnmente en perros adultos jóvenes y en pacientes de raza pequeña. Se presenta por primera vez al Podenco Portugués, el cual además representó la raza con mayor factor de riesgo. Conclusiones. Los resultados obtenidos en esta investigación concuerdan con lo descrito anteriormente en cuanto a las características del paciente con cuerpo extraño esofágico. Asimismo, se reporta el Podenco Portugués como predispuesto a esta entidad, con un factor de riesgo mayor al de otras razas anteriormente mencionadas en la literatura. Para prevenir los cuerpos extraños esofágicos, se debe alimentar con carne cruda y huesos a los perros, especialmente a los de raza pequeña. Siempre se debe tener en cuenta está patología en los perros con sintomatología de enfermedad esofágica sin importar su edad, pues su presentación es más común en perros adultos jóvenes.

Palabras clave: Enfermedad esofágica, esofagoscopia, factor de riesgo (Fuente: MeSH). 


\section{INTRODUCTION}

Esophageal foreign bodies are relatively common in the treatment of small animals, most frequently in dogs. They cause symptoms characteristic of esophagitis like dysphagia, ptyalism and regurgitation (1). Moreover, they can cause severe damage to the esophagus, producing severe esophagitis and cicatricle stenosis as sequela. For these reasons, immediate diagnosis of this pathology is important (2).

Esophageal foreign bodies are more common in dogs than in cats due to their eating habits and way of playing. Among dogs, it is most frequently seen in small breeds, thus research exists where dogs less than $10 \mathrm{~kg}$ are observed to be more greatly affected by esophageal foreign bodies. However, the weight range in some studies varies between 1.8 and $56.0 \mathrm{~kg} \mathrm{(3).}$

The risk factor is defined as the characteristic or factor that is observed to be associated with an increase in probability that the sickness should occur. The term of risk implies that the presence of a factor increases the probability of adverse consequences (4). Among these factors is the breed of dog (5). The factor of relative risk or hazard ratio $(H R)$ is interpreted in the following way: the sickness is HR times more probable to occur in animals exposed to the risk factor than those who have not been exposed (5).

The objective of the present work was to determine characteristics of patients with esophageal foreign bodies to identify the risk factors of this condition.

\section{MATERIAL Y METHODS}

Study Site. The present study was done at the Veterinary Hospital Clinic (VHC) of the University of Extremadura, Cáceres, Spain.

Animals. The work was carried out with dogs with endoscopic diagnosis of an esophageal foreign body. The evaluation parameters were: origin of the patient (referred or internal), sex, age of the patient; dividing this segment in 5 groups: a) less than a year old, b) patients from 1 to 4 years old, c) from 5 to 7 years old, d) from 8 to 10 years old and d) older than 11 . Also, the breed and weight of the patient were taken into account; with this criteria, groups were formed according to size of the breed according to the Federation Cynologique Internationale (FCI): a) miniature breeds or less than $6 \mathrm{~kg}, \mathrm{~b}$ ) small breeds or from 6 to $11.9 \mathrm{~kg}, \mathrm{c}$ ) medium breeds or from 12 to $32.9 \mathrm{~kg}$, d) large breeds or from 33 to $49.9 \mathrm{~kg}$ and d) giant breeds or more than $50 \mathrm{~kg}$.

\section{INTRODUCCIÓN}

Los cuerpos extraños esofágicos son una entidad que se presenta con relativa frecuencia en la clínica de pequeñas especies, más frecuentemente en perros. Causan signología característica de enfermedad esofágica como disfagia, sialorrea y regurgitación (1). Además, pueden causar un daño severo al esófago; produciendo esofagitis severas y estenosis cicatrizales como secuela. Por estos motivos es importante el diagnóstico rápido de esta patología (2).

Los cuerpos extraños esofágicos son más comunes en perros que en gatos debido a sus hábitos alimenticios y a su manera de jugar. Dentro de los perros, se ha visto que son más frecuentes en razas pequeñas, pues existen investigaciones donde se ha observado que perros menores de 10 $\mathrm{kg}$ son mayormente afectados por cuerpos extraños esofágicos, pero los rangos de peso en algunos estudios van de los 1.8 a $56.0 \mathrm{~kg}$ (3).

El factor de riesgo está definido como la característica o factor, que al ser observado está asociado a un aumento de la probabilidad de que aparezca una enfermedad. El término de riesgo implica que la presencia de una característica aumenta la probabilidad de consecuencias adversas (4). Entre estas características se encuentra la raza del perro (5). El factor de riesgo relativo o razón de riesgo (RR) se interpreta de la siguiente manera: la enfermedad es RR veces más probable que ocurra en los animales expuestos al factor de riesgo que en aquellos que no han sido expuestos (5).

El objetivo del presente trabajo fue determinar las características del paciente con cuerpos extraños esofágicos para identificar los factores de riesgo para presentar esta condición.

\section{MATERIAL Y MÉTODOS}

Sitio de estudio. El presente estudio se llevó a cabo en el Hospital Clínico Veterinario (HCV) de la Universidad de Extremadura, Cáceres, España.

Animales. El trabajo se realizó con perros diagnosticados con cuerpo extraño esofágico por medio de endoscopia. Los parámetros a evaluar fueron: procedencia del paciente (remitido o interno), sexo, edad del paciente; dividiéndose este segmento en 5 grupos: a) menores de un año, b) pacientes de entre 1 a 4 años, c) de 5 a 7 años, d) de 8 a 10 años y d) mayores de 11 años. También se tomó en cuenta la raza y el peso del paciente; con este criterio se formaron grupos de acuerdo con el tamaño de las razas según la Federación Cinológica Internacional (FCI):a) 
Experimental Design and Analysis of Statistics. This is a retrospective study carried out over the course of 10 years. With the results that were obtained, a data base was produced with the SPSS program, through which an analysis was made of the frequency of the different parameters and of contingency tables. Also, the risk factor was calculated for breeds of dogs that most frequently presented an esophageal foreign body through endoscopic diagnosis. In addition, the risk factor was calculated for the Spanish Greyhound and the Spanish Mastiff who were fed food scraps and bones. The total number of dogs, attended and sick, and the formula used can be seen in table 1 . The dog breeds to be evaluated were considered as exposed, and every other breed as not exposed, while dogs with an esophageal foreign body were considered sick animals.

Table 1. Formula for the relative risk factor, where exposed dogs are the breeds to be evaluated; not exposed are all other breeds and sick, animals with esophageal foreign objects.

\begin{tabular}{cccc}
\hline & Sick & Healthy & Total \\
\hline Exposed & $\mathrm{a}$ & $\mathrm{b}$ & $\mathrm{a}+\mathrm{b}$ \\
Not exposed & $\mathrm{c}$ & $\mathrm{d}$ & $\mathrm{c}+\mathrm{d}$ \\
\hline Total & $\mathrm{a}+\mathrm{c}$ & $\mathrm{b}+\mathrm{d}$ & $\mathrm{a}+\mathrm{b}+\mathrm{c}+\mathrm{d}$ \\
\hline \multirow{2}{*}{ Riesgo Relativo } & $=$ & $\frac{\text { Incidencia en expuestos }}{\text { Incidencia en no expuestos }}=\frac{I e}{I 0}=\frac{a /(a+b)}{c /(c+d)}$
\end{tabular}

\section{RESULTS}

During 10 years of study, a total of 6,770 dogs were treated by surgery. Through endoscopic diagnosis, thirty of those were found to have an esophageal foreign body, representing $0.44 \%$ of the treated patients.

Esophageal foreign bodies represented $24.06 \%$ of digestive tract endoscopies and also represented $50 \%$ of diagnoses through esophagoscopy. Additionally, $57.69 \%$ of foreign bodies found through an endoscopy were esophageal, $36.58 \%$ were found in the stomach and only $5.76 \%$ in the duodenum. $67.85 \%$ of patients that had an esophagoscopy because of a foreign object were referred.

In relation to the sex of the animals, $56.6 \%$ of patients that had an esophagoscopy because of a foreign object were females and $43.4 \%$ were males. Even through esophageal foreign objects were found in animals that ranged from 1 month to 9 years old, half the patients that had a foreign object in their esophagus were in the 1 to 4 year age group (Figure 1), with a mean of 2 years and 7 months. razas miniatura o menores de $6 \mathrm{~kg}, \mathrm{~b})$ razas pequeñas o de 6 a11.9 $\mathrm{kg}, \mathrm{c}$ ) razas medianas o de 12 a32.9 kg, d) razas grandes o de 33 a 49.9 $\mathrm{kg} \mathrm{y} \mathrm{d)} \mathrm{razas} \mathrm{gigantes} \mathrm{o} \mathrm{de} \mathrm{más} \mathrm{de} 50 \mathrm{~kg}$.

Diseño experimental y análisis estadístico. El presente es un estudio retrospectivo realizado a lo largo de 10 años. Con las fichas obtenidas se elaboró una base de datos en el programa SPSS, mediante el cual se realizaron análisis de frecuencia de los diferentes parámetros, y tablas de contingencia.

También se calculó el factor de riesgo de las razas de perros que más frecuentemente presentaron cuerpo extraño esofágico como diagnóstico endoscópico. También se calculó el factor de riesgo a las razas Galgo Español y Mastín Español por ser alimentados con sobras de alimentos y huesos. El número total de perros atendidos y enfermos y la fórmula utilizada se puede observar en la tabla 1 . Se consideraron como expuestos a los perros de la raza a evaluar, y los no expuestos todas las demás razas y como enfermos los animales con cuerpo extraño esofágico.

\section{RESULTADOS}

Durante 10 años de estudio un total de 6770 perros fueron tratados por el servicio de cirugía. De estos, 30 perros fueron diagnosticados con cuerpo extraño esofágico por vía endoscópica, representando el $0.44 \%$ de los pacientes tratados.

Los cuerpos extraños esofágicos representaron el $24.06 \%$, de las endoscopias del tracto digestivo y además representaron el $50 \%$ de los diagnósticos realizados por esofagoscopia. También, se encontró que $57.69 \%$ de los cuerpos extraños localizados endoscópicamente fueron esofágicos, $36.58 \%$ se encontraron en estómago y tan sólo $5.76 \%$ se localizaron en duodeno. El $67.85 \%$ de los pacientes en los que se realizó esofagoscopia por un cuerpo extraño fueron remitidos.

Con relación al sexo de los animales, el 56.6\% de los pacientes sometidos a esofagoscopia por cuerpo extraño fueron hembras, frente al $43.4 \%$ de machos. Aunque los cuerpos extraños esofágicos fueron observados en animales desde un mes de vida hasta los 9 años, la mitad de los pacientes que presentaron un objeto alojado en el esófago pertenecen al grupo de edad de 1 a 4 años (Figura 1), con una media de 2 años y 7 meses.

El tamaño del paciente también influyó en la frecuencia de aparición de los cuerpos extraños 


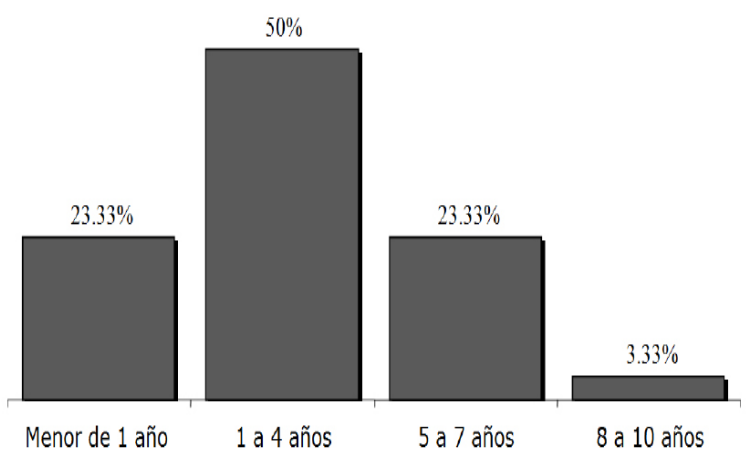

Figure 1. Distribution of patients with esophageal foreign objects according to age. No dogs are older than 11 .

The size of the patient influenced the frequency of appearance of esophageal foreign objects. The study found that almost half of the animals $(48.28 \%$ ) were less than $6 \mathrm{~kg}$ (Figure 2). The size of the patient was a parameter linked to its breed, which is why its influence was also analyzed noticing that $90 \%$ of esophagoscopies done because of foreign objects were on purebred dogs, while only $10 \%$ were done on mix breed dogs. This percentage is low if we take into account that $27.65 \%$ of all patients brought to the $\mathrm{VHC}$ were mix breed dogs. Among the purebreds the Portuguese Warren Hound ( 8 to $20 \mathrm{~kg}$.) was the one that presented the most esophageal foreign objects $(20 \%)$, followed by the Yorkshire Terrier (16.16\%), Miniature Poodle $(13.33 \%)$, West Highland White Terrier (10\%) and others (Figure 3 ).

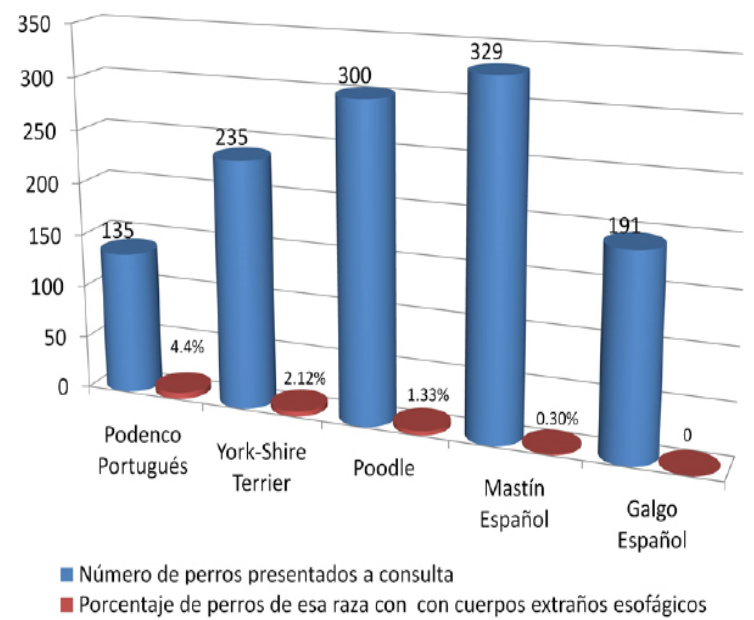

Figure 3. Distribution of dogs with esophageal foreign objects and the relation to the total amount of cases brought in according to breed.

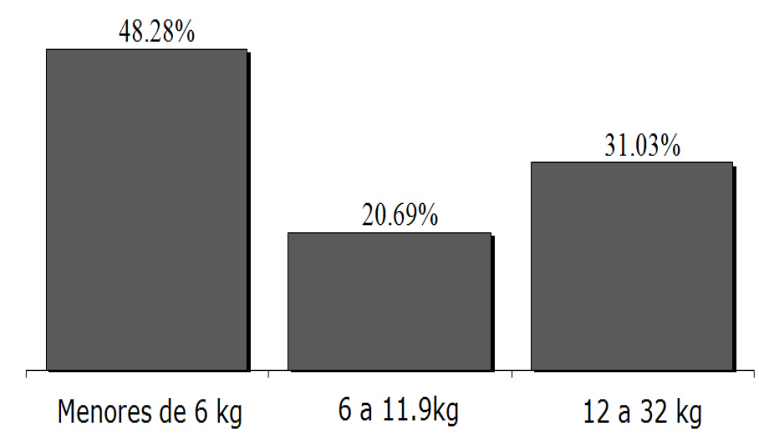

Figure 2. Distribution of patients with esophageal foreign objects according to weight. No dogs were above $32 \mathrm{~kg}$.

esofágicos, ya que se encontró que casi la mitad de los animales del presente estudio (48.28\%) fueron menores a $6 \mathrm{~kg}$ (Figura 2). El tamaño del paciente es un parámetro ligado a su raza, por lo que se analizó también su influencia, advirtiendo que en los perros de raza pura se practican el $90 \%$ de esofagoscopias por cuerpos extraños, mientras que tan sólo se realizaron en el $10 \%$ de perros mestizos. Este porcentaje es escaso si se considera que de todos los pacientes que acuden a la consulta de cirugía del HCV, el $27.65 \%$ son mestizos. Dentro de las razas puras, el Podenco portugués ( $8 \mathrm{a} 20 \mathrm{~kg}$.) fue el que más cuerpos extraños esofágicos presentó (20\%), seguidos por orden descendente del Yorkshire Terrier $(16.16 \%)$, Poodle miniatura $(13.33 \%)$ y West Higland White Terrier (10\%) y otros (Figura 3 ).

\section{DISCUSIóN}

El porcentaje de animales remitidos al HCV para la realización de diagnósticos y tratamiento por cuerpos extraños esofágicos es mayor al de la media de solicitud de esofagoscopias en general, es decir, los veterinarios externos remiten y solicitan esofagoscopias en un mayor número de pacientes cuando la patología es un cuerpo extraño, demostrando así conocer la utilidad de esta técnica en el tratamiento de esta patología.

En el presente estudio, el porcentaje de perros diagnosticados endoscópicamente con cuerpos extraños esofágicos con relación al total de perros atendidos en la sección de cirugía del HCV es similar al presentado recientemente en otra investigación(6), donde mencionan que los cuerpos extraños esofágicos representan $0.32 \%$ de la consulta en el hospital, de igual forma, la cantidad de pacientes presentados con esta entidad durante el período de tiempo es similar al descrito por otros investigadores $(2,3)$. 


\section{DISCUSION}

The percentage of animals referred to the VHC for diagnoses and treatment of esophageal foreign objects is greater than the average of esophagoscopy requests in general. External veterinarians refer and request esophagoscopies to a greater number of patients when the pathology is a foreign object, proving that they recognize the usefulness of this technique in the treatment of this pathology.

In this study, the percentage of dogs endoscopically diagnosed with esophageal foreign objects in relation to the total of dogs attended in the surgery section of the VHC is similar to the one recently shown in another research (6) that mentions that esophageal foreign objects represent $0.32 \%$ of hospital visits. Similarly, the number of patients that visited this institution during the time period is similar to the one described by other researchers $(2,3)$.

At the same time, esophageal foreign objects were the most frequent digestive pathology condition diagnosed through endoscopy $(24.06 \%)$. They also represent $57.69 \%$ of foreign objects in the digestive tract. This study has substantial differences with another retrospective research that showed that $62.96 \%$ of foreign objects were in the stomach, and $22.22 \%$ in the esophagus (7). On the other hand, Aprae et al (8) in 2004 mentioned that of 38 endoscopies on the digestive tract, $38 \%$ presented foreign objects, without differentiating between the esophageal and gastric.

The data obtained in this research on the canine species as the only one that had esophageal foreign object endoscopy is similar to the bibliography. There it mentions that foreign objects are more common in dogs due to the habit of eating without chewing and their playfulness. Additionally, another retrospective study of gastrointestinal foreign objects, mentions that of 17 pets affected, just one was a cat (9).

With regards to the sex of the animals in this study, despite having a slight majority of females, which has already been described by other authors $(9,10)$ this does not represent a meaningful difference.

The age group with most patients was from 1 to 4 years old. This number coincides with a previous study where the average age of dogs with esophagitis by foreign objects was 4 years (10). In human medicine, esophageal foreign
Asimismo, los cuerpos extraños esofágicos fueron la condición más frecuente de todas las patologías digestivas diagnosticadas por endoscopia (24.06\%). Además, representaron el $57.69 \%$ de los cuerpos extraños del tracto digestivo. En este sentido en el presente estudio se registraron diferencias sustanciales con otra investigación retrospectiva en cuya experiencia $62.96 \%$ de los cuerpos extraños fueron de estómago, y $22.22 \%$ de esófago (7). Por otro lado, Apreaet al (8) en 2004 sólo mencionan que de 38 endoscopias del tracto digestivo, $38 \%$ presentaron cuerpos extraños, pero no señalan diferencias entre los esofágicos y los gástricos.

El dato obtenido en este estudio sobre la especie canina como la única presentada a endoscopia por cuerpos extraños esofágicos, es similar a lo descrito en la bibliografía, donde se menciona que los cuerpos extraños son más comunes en los perros debido al hábito de comer sin masticar los alimentos y a su gusto por los juegos. De igual forma, en otro estudio retrospectivo de cuerpos extraños gastrointestinales se menciona que de 17 mascotas afectadas sólo uno era gato (9).

Con respecto al sexo de los animales representados en este estudio, a pesar de existir una ligera mayoría de hembras, lo que ya es descrito por otros autores $(9,10)$, esto no representa una diferencia significativa.

El grupo de edad donde se presentaron más pacientes fue el de 1 a 4 años, dato que coincide por lo presentado en un estudio donde la media de edad de los perros con esofagitis por cuerpos extraños fue de 4 años (10). En medicina humana, los cuerpos extraños esofágicos son más frecuentes en niños de entre 1 y 3 años debido a su inquietud y a la tendencia a introducirse objetos en la boca y simultáneamente llorar, correr o jugar (11). A priori, se podría pensar que los cachorros son más propensos a esta patología que los perros adultos, tanto por su inexperiencia y hábitos de juego como por la extrapolación que se hace de los hallazgos en medicina humana. Sin embargo, los datos presentados en este estudio muestran que no existe evidencia que apoye esta afirmación, pues los perros menores de un año sólo representaron el $23.33 \%$ de los pacientes con cuerpo extraño esofágico en el presente trabajo.

En la presente investigación se confirma que son los animales de talla pequeña los más afectados por esta patología ya que se encuentra alrededor de la mitad de los animales de nuestro estudio $(48.28 \%$ ) fueron menores a $6 \mathrm{~kg}$ (Figura 2). De hecho, la tasa de pacientes es muy elevada si se considera que las razas afectadas concurren 
objects are most common in children between 1 and 3 years old because of their restlessness and their tendency to put things in their mouth while crying, running or playing (11). One could assume that puppies have a higher tendency to suffer from this pathology due to their inexperience and playing habits, and the extrapolation of the findings in human medicine. Data from this study shows that there is no evidence to support that assumption, because dogs under 1 year of age only represented $23.33 \%$ of patients with esophageal foreign objects.

This research confirms that small size dogs are more affected by this pathology, showing that almost half the animals in the study $(48.28 \%)$ were less than $6 \mathrm{~kg}$ (Figure 2). As a matter of fact, the percentage of patients is very high if we take into account that the affected breeds visit the VHC's surgery service in a low proportion; the Yorkshire terrier representing only the $3.39 \%$, and the West highland terrier and the Warren Hound representing only $2 \%$ of the total. The results coincide with those of other authors. There is a retrospective study conducted in 19 veterinary hospitals in the United States in a period of 6 years where the esophageal obstruction caused by dental hygiene treats is described. Of all dogs with this problem the majority were small breeds, representing an $83.9 \%$ (12). At The same time, other studies mention several small breeds with a tendency to have this problem, among them are Poodle (9), Yorkshire terriers $(10,13)$ and West Highland white terrier $(13,14)$.

It is confirmed in the literature that along with the tendency of the West Highland White Terrier, there is an increase in the number of cases because of the new practice of feeding dogs with raw food and bones $(7,15)$. It is evident that these small breeds have a tendency to have esophageal foreign objects, but other small breeds with similar habits like the Chihuahua, the miniature Pinscher and Pomeranian do not present this phenomena at the same rate. For this reason, it is necessary to investigate why certain small breeds have a higher tendency, in order to establish if the Miniature Poodle, the West Highland White Terrier and the Yorkshire Terriers have a relatively narrower esophagus or thorax, or a difference in the size of their abdominal esophagus; this supports the importance of the abdominal esophagus, that according to the La Place law, the greater the size the greater the intra-abdominal pressure producing higher resistance (16). Additionally, a study showed that the portion of the abdominal esophagus has different sizes according to the breed, even reaching the thorax (17). en escasa proporción en el servicio de cirugía del HVU, donde el Yorkshire terrier únicamente representa $3.39 \%$, y tanto el West Higland Terrier como el Podenco tan sólo $2 \%$ del total. Los resultados del estudio concuerdan con los obtenidos por otros autores, pues existe un estudio retrospectivo realizado en 19 hospitales veterinarios de Estados Unidos en un período de 6 años, donde se describe la obstrucción esofágica causada por premios para limpieza dental. De los perros que presentaron este problema la mayoría fueron de raza pequeña representando un $83.9 \%$ (12). Asimismo, otros estudios mencionan a diversas razas pequeñas como las que estan predispuestas a presentar esta entidad, entre ellas el Poodle $(9)$, Yorkshire terriers $(10,13)$ y West Highland White Terrier $(13,14)$.

En la literatura está confirmado que junto con la predisposición del West Highland White Terrier existe un aumento de los casos por la moda de alimentar a los perros con "huesos y comida cruda" (BARF en inglés) $(7,15)$. Está claro que estas razas pequeñas presentan una predisposición a presentar cuerpos extraños esofágicos; sin embargo, en otras razas pequeñas, de hábitos de vida similares como el Chihuahueño, Pinscher miniatura o Pomerania no se da este fenómeno en igual medida. Por este motivo es necesario investigar por qué ciertas razas pequeñas presentan una mayor prevalencia, para establecer si los Poodles Miniatura, West Highland White Terrier y Yorkshire Terriers presentan un esófago o tórax relativamente más estrecho o alguna diferencia en el tamaño del esófago abdominal; esto último apoyado en que la longitud el esófago abdominal es muy importante, pues según la ley de La Place, a mayor tamaño la presión intraabdominal aumenta y produce una mayor resistencia (16). Además, en una investigación encontraron que la porción del esófago abdominal tiene diferentes medidas según la raza, incluso localizándose en el tórax (17).

Con la presente investigación también se ha publicado una comunicación donde se reporta al Podenco Portugués como la raza con más diagnósticos de cuerpos extraños esofágicos (17). Es fácil pensar que esta raza es la más afectada al ser común en la península, y por la tendencia a alimentar con sobras y huesos a los perros de cacería en Extremadura, España. Sin embargo, otras razas alimentadas con huesos comúnmente presentadas al HCV como el Mastín Español presentó un factor de riesgo muy bajo y el Galgo Español no presentó ningún cuerpo extraño esofágico (Tabla 2). 
Along with this research a report has been published mentioning that the Portuguese Warren Hound is the breed with more diagnoses of esophageal foreign objects (17). It is easy to think that this breed is the most affected because of how common it is in the Peninsula and the tendency to feed hunting dogs with bones and scraps in Extremadura, Spain. However, other breeds fed with bones commonly brought into the VHC like the Spanish Mastiff, had a very low risk factor and the Spanish Greyhound did not present esophageal foreign objects (Table 2 ).

The risk factor is a characteristic or factor associated to the increase in the probability of developing a sickness $(4,5)$. The breed can, therefore, be considered a risk factor (5). Based on this data one concludes that there is a tendency of the Portuguese Warren Hound to have esophageal foreign objects. This breed's relative risk factor is 9.81 , the highest of the study, even higher than the breeds traditionally considered of high risk like the Yorkshire Terrier and the Poodle.

A limiting factor of this study is the number of patients brought in with esophageal foreign objects; nevertheless, there are other publications with a similar number of patients $(2,3,6)$. It is important to take into account that to calculate the relative risk prevalence rate, the population is all the patients that visited a veterinary school clinic or a reference clinic (18) as in the case of the VHC of the Universidad de Extremadura.

In conclusion the results of this research coincide with what has been previously described in terms of characteristics of the patient with esophageal foreign objects. It is also reported that the Portuguese Warren Hound has a predisposition to suffer this ailment, with a higher risk factor than other breeds in Spain. This pathology always needs to be taken into account with dogs with esophageal sickness symptomatology regardless of its age, because it is more common in young adult dogs. Finally, to prevent esophageal foreign objects, dogs, especially small breeds, should not be fed raw meat and bones.
Table 2. Relative risk factor of different dog breeds with esophageal foreign objects.

\begin{tabular}{lccc}
\hline \multicolumn{1}{c}{ Breed } & $\begin{array}{c}\text { Total dogs } \\
\text { brought in }\end{array}$ & $\begin{array}{c}\text { Total dogs with } \\
\text { esophageal } \\
\text { foreign objects. }\end{array}$ & $\begin{array}{c}\text { Relative } \\
\text { risk to have } \\
\text { esophageal } \\
\text { foreign object }\end{array}$ \\
\hline $\begin{array}{l}\text { Portuguese } \\
\text { Warren Hound }\end{array}$ & 135 & 6 & 9.81 \\
York-Shire Terrier & 235 & 5 & 5.5 \\
Poodle & 300 & 4 & 3.3 \\
$\begin{array}{l}\text { Spanish Mastiff } \\
\text { Spanish }\end{array}$ & 329 & 1 & 0.05 \\
Greyhound & 191 & 0 & 0.0 \\
Total dogs & 6770 & 30 & \\
\hline
\end{tabular}

El factor de riesgo es una característica o factor asociado con un aumento en la probabilidad de que aparezca una enfermedad $(4,5)$. Por lo tanto, la raza puede ser considerada como un factor de riesgo (5). Con baseen estos datos, se concluye que existe predisposición del Podenco Portugués a presentar cuerpos extraños esofágicos, pues el factor de riesgo relativo de 9.81 es el más elevado del estudio, siendo mayor que el de razas tradicionalmente consideradas de alto riesgo como el York-Shire Terrier y Poodle.

Como limitante de este estudio se tiene el número de pacientes presentados con cuerpo extraño esofágico; sin embargo, existen publicaciones con un número similar de pacientes $(2,3,6)$. Es importante considerar que para el cálculo de las tasas de prevalencia de riesgos relativos se pueden tomar en cuenta la como población a todos los pacientes que hayan acudido a un hospital de enseñanza o de referencia (18), como el caso del HVU de la Universidad de Extremadura.

En conclusión los resultados obtenidos en esta investigación concuerdan con lo descrito anteriormente en cuanto a las características del paciente con cuerpo extraño esofágico. Empero, se reporta el Podenco Portugués como predispuesto a esta entidad, con un factor de riesgo mayor que el de otras razas en España. Siempre se debe tener en cuenta está patología en los perros con sintomatología de enfermedad esofágica sin importar su edad, pues su presentación es más común en perros adultos jóvenes. Finalmente, para prevenir los cuerpos extraños esofágicos, no se debe alimentar con carne cruda y huesos a los perros, especialmente a los de raza pequeña. 


\section{REFERENCES}

1. Moon J-H, Kang B-T, Kwon D-H, Lee H-C, Jeon J-H, Cho K-W, et al. Esophageal and Gastric Endoscopic Foreign Body Removal of 19 Dogs (2009-2011) Future Information Technology, Application, and Service. Netherlands:Springer; 2012.

2. Thompson HC, Cortes Y, Gannon K, Bailey D, Freer S. Esophageal foreign bodies in dogs: 34 cases (2004-2009). Vet Emerg Crit Care 2012; 22:253-261. doi: 10.1111/j.14764431.2011.00700.x

3. Juvet $F$, Pinilla M, Shiel RE, Mooney CT. Oesophageal foreign bodies in dogs: factors affecting success of endoscopic retrieval. Ir Vet J 2010; 63(3):163-168.

4. Reyes Romagosa DE, Rosales Rosales K, Roselló Salcedo O, García Áreas DM. Factores de riesgo asociados a hábitos bucales deformantes en niños de 5 a 11 años. Policlínica René Vallejo Ortiz de Manzanillo 2004 - 2005. Acta Odontol Venez 2007; 45(3):394-401.

5. Pfeiffer D. Veterinary Epidemiology: An Introduction. Chichester, United Kingdom: Wiley-Blackwell; 2010.

6. Gianella P, Pfammatter NS, Burgener IA. Oesophageal and gastric endoscopic foreignbody removal: complications and follow-up of 102 dogs. J Small Anim Pract 2009; 50(12):649-654.

7. Villalobos J. Extracción de cuerpos extrañospor endoscopia flexible (endocirugía) en perrosy gatos. Experiencia clínica de dos años. Rev AMMVEPE 2002; 13(3): 94-97.

8. Aprea A, Giordano A, Bonzo E. Endoscopia en pequeños animales. Informe de su implementación en el hospital de clínica de la Facultad de Ciencias Veterinarias Universidad nacional de la plata. Analecta Vet $2004 ; 24(2): 10-15$.

9. Mudado MA, Del CarloRJ, BorgesAPB, CostaPRDS. Digestive tract obstruction in pets attended in a Veterinary Hospital during 2010. Rev Ceres 2012; 59(4):434-445.
10. Rousseau A, Prittie J, Broussard JD, Fox PR, Hoskinson J. Incidence andcharacterization of esophagitis followingesophageal foreign body removal in dogs: 60cases (1999-2003). Vet Emerg Crit Care 2007; 17(2):159-163.

11. Rodríguez $\mathrm{H}$, Cuestas $\mathrm{G}$, Botto $\mathrm{H}$, Nieto $\mathrm{M}$, Cocciaglia A, Gregori D. Cuerpos extraños en el esófago en los niños: Serie de casos. Arch Argent Pediatr 2013; 111(3):e62-e65.

12. Leib MS, Sartor LL. Esophageal foreignbody obstruction caused by a dental chew treatin 31 dogs (2000-2006). J Am Vet Med Assoc 2008; 232(7):1021-1025.

13. Jankowski M, J Spużak, K Kubiak, K GlińskaSuchocka, J Nicpoń. Oesophageal foreign bodies in dogs. Pol J Vet Sci 2013; 16(3), 571-2.

14. Elwood C. Diagnosis and management ofcanineoesophageal disease and regurgitation. In Pract 2006; 28:14-21.

15. Fossum TW, Dewey CW, Horn CV, Johnson AL, MacPhail CM, Radlinsky MAG. Small Animal Surgery, 4 ed., St. Louis: Elsevier Mosby; 2013.

16. Pratschke KM, Fitzpatrick $E$, Campion $D$, McAllister $\mathrm{H}$, Bellenger CR. Topography of the gastro-oesophageal junction in the dog revisited: possible clinical implications. Res Vet Sci 2004; 76(3):171-177.

17. Rodríguez-AlarcónCA, Usón J, Beristain DM, Rivera R, Andres S, Pérez EM. Breed as risk factor for oesophageal foreign bodies. J Small Anim Pract 2010; 51(6):357.

18. Pérez $C$. Análisis del registro de tumores del Hospital Clínico Veterinario de la UCM (19912003). [Tesis doctoral]. Madrid, España: Universidad Complutense de Madrid, Facultad de Veterinaria; Departamento de Medicina y Cirugía Animal; 2005. 